$W_{E}$ investigated the serum concentration of endostatin in 84 patients with multiple myeloma (MM) and in 13 healthy controls. The level of measured antiangiogenic agent was correlated with the phase and stage of the disease, and most importantly with clinical and laboratory parameters depicting the disease activity (haemoglobin, creatinine, albumins, calcium, M-component, $\mathrm{C}$-reactive protein, $\boldsymbol{\beta 2}$-microglobulin, lactate dehydrogenase, stage of bone disease) as well as serum levels of pro-angiogenic cytokines such as vascular endothelial growth factor, hepatocyte growth factor, fibroblast growth factor and transforming growth factor- $\beta$. The median serum level of endostatin in MM patients was $58 \mathrm{ng} / \mathrm{ml}$ and was statistically significantly higher than in the control group (median, $40 \mathrm{ng} / \mathrm{ml} ; p=0.015$ ). MM patients in phase I (at diagnosis) had higher levels of endostatin (median, $69 \mathrm{ng} / \mathrm{ml}$ ) than those in phase II (plateau phase after treatment) (median, $49 \mathrm{pg} / \mathrm{ml}$; $p=0.044)$. We did not find any statistical correlation between the level of endostatin and stage of MM according to the Durie and Salmon system. The serum concentration of endostatin in MM patients with a normal level of albumins was significantly higher than in others with hypoalbuminaemia (median, $62 \mathrm{ng} / \mathrm{ml}$ versus $39 \mathrm{ng} / \mathrm{ml} ; p=0.033$ ). Also, patients with a normal value of lactate dehydrogenase had a higher concentration of endostatin than those with values $>425 \mathrm{U} / 1$ (median, $70 \mathrm{ng} / \mathrm{ml}$ versus $39 \mathrm{ng} / \mathrm{ml} ; \boldsymbol{p}=0.019)$. We did not show any statistical correlation between the concentration of endostatin and level of haemoglobin, creatinine, calcium, $C$ reactive protein, $\beta 2$-microglobulin and stage of bone disease. We failed to find positive or negative correlations between the level of endostatin and vascular endothelial growth factor, hepatocyte growth factor, fibroblast growth factor and transforming growth factor- $\beta$. The concentration of endostatin did not influence the probability of survival in MM patients in our study.

In conclusion, our data indicate that endostatin has a higher level in MM patients than in healthy controls. Highest values were stated in active phases of the disease (at presentation and in progression). Different clinical and laboratory parameters generally do not influence the concentration of endostatin (except albumins and lactate dehydrogenase).

Key words: Multiple myeloma, Endostatin, Angiogenic cytokines, Serum levels, Clinical significance

\section{High serum level of endostatin in multiple myeloma at diagnosis but not in the plateau phase after treatment}

\author{
Halina Urbańska-Ryś and Tadeusz Robak ${ }^{\text {CA }}$
}

Department of Haematology, Medical University of Lodz, Copernicus Memorial Hospital, Pabianicka 62 st., 93-513 Lodz, Poland

\author{
${ }^{\mathrm{CA}}$ Corresponding Author \\ Tel: +48426895191 \\ Fax: +48426895192 \\ E-mail: robaktad@csk.am.lodz.pl
}

\section{Introduction}

Angiogenesis is the key process in growth and metastatic spread of neoplasms. In normal tissues blood vessel growth is minimal and angiogenesis is controlled by a balance of angiogenic stimulators and inhibitors. This balance is perturbed in tumours to favour angiogenesis either by overproduction of angiogenesis inducers or by lack of inhibitors. ${ }^{1}$ The shift in balance between the production of antiangiogenic and pro-angiogenic factors is a process called angiogenic switch and it marks the onset of neovascularization, which is probably a key step during tumour progression. ${ }^{1,2}$ In earlier data it was suggested that the generation of anti-angiogenic compounds in the presence of primary tumour suppresses the growth of distant metastases. ${ }^{3}$

Recently, several naturally occurring inhibitors of angiogenesis have been identified. The most potent 
of them appears to be endostatin, the $20 \mathrm{kDa} C$ terminal proteolytic fragment of the basement membrane component collagen XVIII, isolated by O'Reilly et $a l .{ }^{4}$ Endostatin is implicated in the regulation of physiological and pathological angiogenesis. Its precise mechanism of action is still unclear. Endostatin inhibits endothelial cell proliferation in vitro. 5,6 Different investigators have proposed the interference of endostatin with such pro-angiogenic cytokines as vascular endothelial growth factor (VEGF) and fibroblast growth factor (FGF) (basic fibroblast growth factor (bFGF)) pathways, ${ }^{7}$ induction of endothelial cell apoptosis, ${ }^{8,9}$ inhibition of matrix metalloproteases, ${ }^{10}$ and inhibition of endothelial cell migration by modulating c-myc levels. ${ }^{11}$

Endostatin possesses a prominent heparan sulphate binding domain, although it is not clear whether this domain is required for anti-angiogenic activity. ${ }^{6,12}$ According to MacDonald et al., endostatin binds tropomyosin in vitro and to tropomyosinassociated microfilaments in a variety of endothelial cell types. ${ }^{13}$ The authors postulate that the interaction of endostatin with tropomyosin results in the disruption of microfilament integrity, leading to the inhibition of cell motility, induction of apoptosis and inhibition of tumour growth. Endostatin levels liberated into culture media and administered exogenously are decreased by hypoxia, the principal cause of angiogenesis. ${ }^{14}$

Recent successes in producing active human recombinant endostatin in yeast have allowed testing this protein in an animal model, ${ }^{15,16}$ in vitro, ${ }^{17}$ and in clinical studies. ${ }^{18}$ Endostatin was shown to induce tumour stabilization after chemotherapy or anti-CD20 immunotherapy in a mouse model of human highgrade non-Hodgkin lymphoma. Tumour growth was prevented in endostatin-treated mice as long as the drug was administered. Enostatin administered on days 25-29 after tumour re-growth still induced significant tumour regression, whereas chemotherapy and anti-CD20 immunotherapy were not effective. $^{15}$ Fujii et al. demonstrated that endostatin inhibits multiple myeloma (MM) growth and tumour burden in the SCID-hu host system. It was reflected by a reduction in serum levels of human monoclonal immunoglobulins. Furthermore, mice bone density was preserved, as demonstrated by X-ray evaluation. ${ }^{19}$ This fact may have therapeutical implications. $^{20}$

There is evidence that different diseases such as connective tissue diseases, solid tumours, sarcomas and even Down's syndrome play a role in the generation of endogenous anti-angiogenic proteins, including endostatin. ${ }^{21-26}$ Bertolini et al. first reported plasma levels of endostatin in heamatologic malignancies (non-Hodgkin lymphoma patients). The authors did not notice any difference between these levels in complete remission and progression of the disease, as well as no correlation being found between endostatin levels and event-free survival. ${ }^{15}$ Kay et al. detected mRNA for endostatin in chronic lymphocytic leukemia (CLL) patients. ${ }^{27}$

MM cells are known to secrete pro-angiogenic cytokines such as VEGF and FGF in vitro and in vivo. VEGF expression is correlated with the severity of the disease, and circulating VEGF is a prognostic factor for the survival of MM patients. ${ }^{28}$ Increased angiogenesis in MM should result in high endostatin value. The role of this most potent inhibitor of angiogenesis is established on in vitro and animal models also in $\mathrm{MM},{ }^{16,19}$ but its clinical significance is not elucidated at present.

Recent data demonstrate that MM cells can produce anti-angiogenic as well as pro-angiogenic factors. In the present study we compare endostatin serum level in different phases and stages of MM using the enzyme-linked immunosorbent assay and correlate its concentration with pro-angiogenic cytokines such as VEGF, hepatocyte growth factor (HGF), FGF and transforming growth factor- $\beta$ (TGF- $\beta$ ).

\section{Patients and methods}

\section{Patients}

The study group comprised 84 patients with MM and 13 healthy controls comparable for median age and gender distribution to the patient population. The patients' characteristics are presented in Table 1.

There were 43 women and 41 men with mean age 66.5 years (range, $32-88$ years) in the patient group. The control group comprised seven women and six men with mean age 65.9 years (range, 47-80 years).

Table 1. Clinical and laboratory characteristics of MM patients

\begin{tabular}{|c|c|}
\hline Clinical/laboratory feature & Number of patients (\%) \\
\hline Total & $84(100)$ \\
\hline Sex (male/female) & $45 / 43$ \\
\hline Age (years) [median (range)] & $68(32-88)$ \\
\hline Phase I & $57(68)$ \\
\hline Phase II & $16(19)$ \\
\hline Phase III & $11(13)$ \\
\hline Stage I & $20(24)$ \\
\hline Stage II & $16(19)$ \\
\hline Stage III & $48(57)$ \\
\hline Bone disease & $29 / 77(38)$ \\
\hline M-protein IgG & $56(67)$ \\
\hline M-protein IgA & $13(15.5)$ \\
\hline M-protein light chain & $13(15.5)$ \\
\hline Non-secretory MM & $2(2)$ \\
\hline Creatinine $>2 \mathrm{mg} / \mathrm{dl}$ & $66(79)$ \\
\hline Haemoglobin $<10 \mathrm{~g} / \mathrm{dl}$ & $39(46)$ \\
\hline Albumin $<30 \mathrm{~g} / \mathrm{l}$ & $16(19)$ \\
\hline Calcium $<9 \mathrm{mg} / \mathrm{dl}$ & $23(27)$ \\
\hline Calcium > $11 \mathrm{mg} / \mathrm{dl}$ & $11(13)$ \\
\hline $\mathrm{LDH}>425 \mathrm{U} / \mathrm{I}$ & $26(31)$ \\
\hline $\mathrm{LDH}<210 \mathrm{U} / \mathrm{I}$ & $10(12)$ \\
\hline $\mathrm{CRP}>5 \mathrm{mg} / \mathrm{l}$ & $29(34.5)$ \\
\hline$\beta 2$-microglobulin $>2.5 \mathrm{mg} / \mathrm{l}$ & $59(70)$ \\
\hline
\end{tabular}


Immunoglobulin (Ig)G myeloma was diagnosed in 69 patients, IgA in 13 patients, light chain disease in four patients and non-secretory myeloma in two cases. Fifty-seven patients were studied at diagnosis (phase I), 16 in the plateau (phase II) and 11 in the relapsed disease (phase III). The plateau phase was stated after 3 months of stable disease and achieving complete (disappearance or decrease of M-component $>90 \%$ ) or partial (M-component decrease $>50 \%$ ) remission after chemotherapy. Twenty patients were diagnosed in clinical stage I (IA, 20 patients; IB, 0 patients), 17 patients in clinical stage II (IIA, 14 patients; IIB, three patients) and 47 patients in clinical stage III (IIIA, 32 patients; IIIB, 15 patients) according to the Durie and Salmon system. ${ }^{29}$ Renal failure (substage B) was diagnosed when the level of creatinine was $>2 \mathrm{mg} / \mathrm{ml}$, and was observed in 18 patients. Advanced bone disease was stated in 29 out of 77 patients with at least multiple lytic lesions found in X-ray examination. MM patients were treated with different chemotherapy protocols adjusted to their age and clinical status. One patient received highdose chemotherapy.

\section{Laboratory examinations}

All laboratory tests were performed on the day of blood sampling for endostatin assay. Each patient's blood sample was examined for the following parameters: complete heamogram, serum protein electrophoretogram, immunoglobulins, urea nitrogen, creatinine, calcium, lactate dehydrogenase (LDH), C-reactive protein (CRP), $\beta 2$-microglobulin, VEGF, HGF, FGF and TGF- $\beta$. Serum $\beta 2$-microglobulin levels were measured by means of a radioimmunoassay kit. Correction for renal function was not calculated. Levels of immunoglobulins, albumin and CRP were measured by nephelometry. Normal values of CRP were considered as below $5.0 \mathrm{mg} / \mathrm{l}$. Bone marrow examination was performed in all cases, and X-ray survey of flat bones in 77 patients.

\section{Cytokine determination}

Venous blood samples were collected on the day of physical examination and laboratory tests. They were collected in pyrogen-free tubes, allowed to clot for 1 $\mathrm{h}$ at $4^{\circ} \mathrm{C}$ and centrifuged at $2000 \mathrm{xg}$ for $10 \mathrm{~min}$. The obtained sera were aliquoted into separate vials and stored at $-80^{\circ} \mathrm{C}$ until assayed for endostatin and other cytokines. Sera from each patient were randomly coded and the measurement of cytokines was carried out without the knowledge of the patient's clinical status and laboratory data. The obtained sera were assayed for the concentration of endostatin (also for VEGF, HGF, bFGF and TGF- $\beta 1$ ). The commercially available enzyme-linked immunosorbent assay kit produced by Oncogene Research Products (Boston,
MA, USA) was used for endostatin detection, and Quantikine, R \& D Systems Inc. (Minneapolis, MN, USA) products were used for the determination of the remaining cytokines. All manufacturers' instructions were followed. The adsorbance was read at $492 \mathrm{~nm}$. The appropriate recombinant human cytokine was used to generate the standard curve for each assay. The concentration of cytokines in the samples was determined by the interpolation from the standard curve. This procedure has been described precisely in our previous works. ${ }^{30,31}$ The sensitivity limit for endostatin was $1.95 \mathrm{ng} / \mathrm{ml}$, for VEGF was $5.0 \mathrm{pg} / \mathrm{ml}$, for $\mathrm{HGF}$ was $40 \mathrm{pg} / \mathrm{ml}$, for TGF- $\beta 1$ was $7 \mathrm{pg} / \mathrm{ml}$ and for bFGF was $3 \mathrm{pg} / \mathrm{ml}$.

\section{Statistical analysis}

Statistical analysis was performed using the procedures of Statistica for Windows package on the IBMcompatible computer. The significance of cytokine levels in different subsets of patients was assessed by Mann-Whitney U, Kruskall-Wallis, Cochran-Cox and Student tests where appropriate. $p$ values obtained from pair-wise comparisons were corrected with the Bonferroni method. Zero values indicating undetectable levels of cytokines were included in all analyses. Correlations of analysed cytokines with laboratory parameters and between cytokines were calculated with Spearman's rank sum correlation coefficient. All values quoted are two sided and designated as statistically significant at the level $<0.05$. The overall survival was estimated using the Kaplan-Meier method from the beginning of the disease. All endpoints were updated on 31 August 2002. The survival period was analysed in two groups of patients, below and above the median concentration value of endostatin, and compared using the FCox test.

\section{Results}

The serum concentration values of endostatin in MM patients and healthy controls are presented in Table 2. Serum levels of endostatin were detectable in all patients and in 12 out of 13 controls. The mean concentration in the MM group was $72 \mathrm{ng} / \mathrm{ml}$ (range, 11-402 $\mathrm{ng} / \mathrm{ml}$ ). The mean concentration of this inhibitor in controls was $38 \mathrm{ng} / \mathrm{ml}$ (range, 0.0-81 $\mathrm{ng} / \mathrm{ml} ; p=0.015)$. The mean level of endostatin was highest in phases I and III of MM (mean, $77 \mathrm{ng} / \mathrm{ml}$ and $80 \mathrm{ng} / \mathrm{ml}$, respectively). The concentration of this agent in phase II was lower at $48 \mathrm{ng} / \mathrm{ml}$, and there was a statistically significant difference between the level of endostatin in phases I and II of the disease $(p=0.044)$. The stage of MM according to Durie and Salmon 
Table 2. Serum levels of endostatin in MM patients at different phases

\begin{tabular}{ll}
\hline MM patients & \multicolumn{1}{c}{$\begin{array}{c}\text { Serum level of } \\
\text { endostatin } \\
\text { (ng/ml) }\end{array}$} \\
\hline a. All $(n=84)$ & $72 \pm 63[58(11-402)]$ \\
b. Phase $-1(n=57)$ & $77 \pm 65[69(11-402)]$ \\
c. Phase $-2(n=16)$ & $48 \pm 20[49(21-87)]$ \\
d. Phase $-3(n=11)$ & $80 \pm 85[50(27-296)]$ \\
e. Control group $\left(n=13, n_{1}=12\right)$ & $38 \pm 22[40(0-80)]$ \\
Statistically significant comparison & b versus c, $p=0.04$ \\
& b versus e, $p=0.008$ \\
\hline
\end{tabular}

Data presented as mean \pm standard deviation [median (range)]. Phase 1 , at the beginning; phase 2, plateau; phase 3 , progression. $n$, number of investigated individuals; $n_{1}$, number of individuals with detectable endostatin.

classification as well as stage of bone disease did not influence the endostatin concentration (Table 2).

The mean concentration of endostatin in MM patients with a normal level of albumins ( $>30 \mathrm{~g} / \mathrm{l}$ ) was $78 \mathrm{ng} / \mathrm{ml}$, and was significantly higher than in those with hypoalbuminaemia ( $46 \mathrm{ng} / \mathrm{ml} ; p=0.033$ ). Similar results were obtained in correlation of endo-

Table 3. Serum level of endostatin in MM patients correlated with clinical and laboratory parameters

\begin{tabular}{|c|c|c|}
\hline $\begin{array}{l}\text { Laboratory/ } \\
\text { Clinical } \\
\text { parameter }\end{array}$ & $\begin{array}{l}\text { Serum level of } \\
\text { endostatin } \\
(\mathrm{ng} / \mathrm{ml})\end{array}$ & $\begin{array}{l}\text { Statistical } \\
\text { significance }\end{array}$ \\
\hline $\begin{array}{l}\text { Haemoglobin } \\
>10 \mathrm{~g} / \mathrm{dl} \\
<10 \mathrm{~g} / \mathrm{dl} \\
\text { Creatinine }\end{array}$ & $\begin{array}{l}68 \pm 55 \\
77 \pm 70\end{array}$ & Not significant \\
\hline $\begin{array}{l}>2 \mathrm{mg} / \mathrm{dl} \\
<2 \mathrm{mg} / \mathrm{dl} \\
\text { Albumins }\end{array}$ & $\begin{array}{l}78 \pm 91 \\
71 \pm 54\end{array}$ & Not significant \\
\hline $\begin{array}{l}>30 \mathrm{~g} / \mathrm{l} \\
<30 \mathrm{~g} / \mathrm{l} \\
\text { Calcium }\end{array}$ & $\begin{array}{l}78 \pm 67 \\
46 \pm 25\end{array}$ & 0.033 \\
\hline $\begin{array}{l}>11 \mathrm{mg} / \mathrm{dl} \\
9-11 \mathrm{mg} / \mathrm{dl} \\
<9 \mathrm{mg} / \mathrm{dl} \\
\text { M-component }\end{array}$ & $\begin{array}{l}73 \pm 61 \\
66 \pm 42 \\
85 \pm 97\end{array}$ & Not significant \\
\hline $\begin{array}{l}\text { IgG } \\
\text { IgA } \\
\text { Light chain } \\
\text { CRP }\end{array}$ & $\begin{array}{l}75 \pm 59 \\
83 \pm 107 \\
49 \pm 23\end{array}$ & Not significant \\
\hline $\begin{array}{l}>5 \mathrm{mg} / \mathrm{l} \\
<5 \mathrm{mg} / \mathrm{l} \\
\beta 2 \text {-microglobulin }\end{array}$ & $\begin{array}{l}68 \pm 68 \\
76 \pm 58\end{array}$ & Not significant \\
\hline $\begin{array}{l}>2.5 \mathrm{mg} / \mathrm{l} \\
<2.5 \mathrm{mg} / \mathrm{l} \\
\mathrm{LDH}\end{array}$ & $\begin{array}{l}74 \pm 68 \\
67 \pm 49\end{array}$ & Not significant \\
\hline $\begin{array}{l}\text { a. }>425 \mathrm{U} / \mathrm{l} \\
\text { b. } 210-425 \mathrm{U} / \mathrm{I} \\
\text { c. }<210 \mathrm{U} / \mathrm{I} \\
\text { Stage of disease }\end{array}$ & $\begin{array}{l}71 \pm 87 \\
77 \pm 51 \\
52 \pm 33\end{array}$ & a versus $b, p=0.019$ \\
\hline $\begin{array}{l}\text { la } \\
\text { liia } \\
\text { lib } \\
\text { IIIa } \\
\text { IIIb }\end{array}$ & $\begin{array}{r}68 \pm 62 \\
71 \pm 60 \\
46.0 \pm 15 \\
72 \pm 48 \\
85 \pm 99\end{array}$ & Not significant \\
\hline $\begin{array}{l}\text { Bone disease } \\
0-1 \text { stage } \\
2-3 \text { stage }\end{array}$ & $\begin{array}{l}67 \pm 57 \\
82 \pm 80\end{array}$ & Not significant \\
\hline
\end{tabular}

Data presented as mean \pm standard deviation. statin with LDH. In patients with a normal concentration of LDH $(<210$ and $>425 \mathrm{U} / \mathrm{l})$, the mean level of this factor was significantly higher than in patients with elevated LDH values $(77 \mathrm{pg} / \mathrm{ml}$ versus $71 \mathrm{pg} / \mathrm{ml}$, $p=0.019)$. The level of endostatin was lowest in light chain disease patients (mean, $49 \mathrm{ng} / \mathrm{ml}$ ) in comparison with IgG MM (mean, $75 \mathrm{ng} / \mathrm{ml}$ ) and IgA MM (mean, $83 \mathrm{ng} / \mathrm{ml}$ ). The light chain type did not influence the level of this inhibitor. Endostatin concentration did not correlate with other analysed laboratory parameters such as haemoglobin, creatinine, total protein, calcium, CRP and $\beta 2$-microglobulin (Table 3).

In two patients with non-secretory MM, the endostatin concentrations were 35 and $68 \mathrm{ng} / \mathrm{ml}$.

The endostatin serum level was correlated with some pro-angiogenic cytokines such as VEGF, HGF, FGF and TGF- $\beta$ (Table 4). We did not find any statistically significant correlation between endostatin and these cytokines (Fig. 1).

The serum concentration of endostatin higher or lower than its median value did not influence the probability of survival of MM patients (Fig. 2).

\section{Disscusion}

The aim of our study was to evaluate the serum concentration of an anti-angiogenic agent (endostatin) in patients with $\mathrm{MM}$, and to correlate it with disease activity and advancement, the most important clinical and laboratory parameters as well as known pro-angiogenic cytokines such as VEGF, HGF, FGF and TGF- $\beta$. The level of endostatin was detectable in all 84 analysed MM patients and in 12 out of 13 healthy cotrols. Most authors report the detection of endostatin in serum of the vast majority of patients with solid tumours, soft tissue sarcomas, autoimmune diseases and haematologic malignancies. ${ }^{21-23,26,27,32}$

In our study, the concentration of endostatin in MM patients was significantly higher than in healthy individuals in comparable age. Higher values of this agent were found in patients with MM before treatment (phase 1 of the disease) than after therapy (phase 2). We found no significant increase of endostatin in advanced stages - IIIA and IIIB of the disease according to the Salmon and Durie system - as well as in advanced stages of bone disease. The aggressiveness of MM in our data has no association with the level of endostatin. Higher values of that inhibitor were found in MM patients with a normal level of albumins in comparison with those with hypoalbuminaemia. Similarly, in cases of MM with normal values of LDH, endostatin had higher concentrations than in other patients with decreased or elevated levels of LDH. We found no correlation between the level of endostatin and the 
Table 4. Serum levels of VEGF, HGF, FGF and TGF- $\beta$ in MM patients

\begin{tabular}{lcccc}
\hline Serum level/cytokine & VEGF $(\mathrm{pg} / \mathrm{ml})$ & HGF $(\mathrm{pg} / \mathrm{ml})$ & $\mathrm{FGF}(\mathrm{pg} / \mathrm{ml})$ & $\mathrm{TGF}-\beta(\mathrm{ng} / \mathrm{ml})$ \\
\hline Mean \pm standard deviation & $324 \pm 305$ & $1940 \pm 1400$ & $8 \pm 19$ & $37 \pm 15$ \\
Median & 232 & 1270 & 2 & 36 \\
Range & $23-1668$ & $579-4674$ & $0-108$ & $3-81$ \\
\hline
\end{tabular}

remaining analysed laboratory parameters (haemoglobin, creatinine, total protein value, calcium, CRP, $\beta 2$-microglobulin, immunoglobulin and light chain isotype). Similar results were reported by Bertolini et al. in non-Hodgkin lymphoma patients. ${ }^{15}$ These authors also stated lack of correlation between endostatin levels with the grade of tumour malignancy. They also found no difference in endostatin concentration between patients in complete remission and progressive disease. Our data suggest that the serum level of endostatin is lower in cases after therapy and highest before treatment and in progression of MM. Feldman et al. measured the level of endostatin in soft tissue sarcoma patients and stated that the high pre-operative serum level predicted poorer outcome. ${ }^{21}$ Lai et al. showed that endostatin has prognostic value in predicting complete remission and overall survival in patients with acute myeloid leukaemia and myelodysplastic syndromes. $^{32}$

In our previous study we showed positive correlations between pro-angiogenic cytokines (VEGF and TGF- $\beta$, bFGF and TGF- $\beta$, VEGF and bFGF) and our data indicated a strong relationship between the serum levels of these cytokines and clinical course, as well as selected laboratory parameters of patients with $\mathrm{MM}^{28}$ In this study we failed to prove the correlation of the most potent anti-angiogenic factor, endostatin, with these most clinically relevant proangiogenic cytokines. Probably their interaction is not direct, and further research is needed to elucidate this problem.

We found no influence of endostatin level on the probability of survival in our patients with MM. Previously we stated that VEGF and FGF concentrations have an effect on MM patients' survival. ${ }^{28}$ The
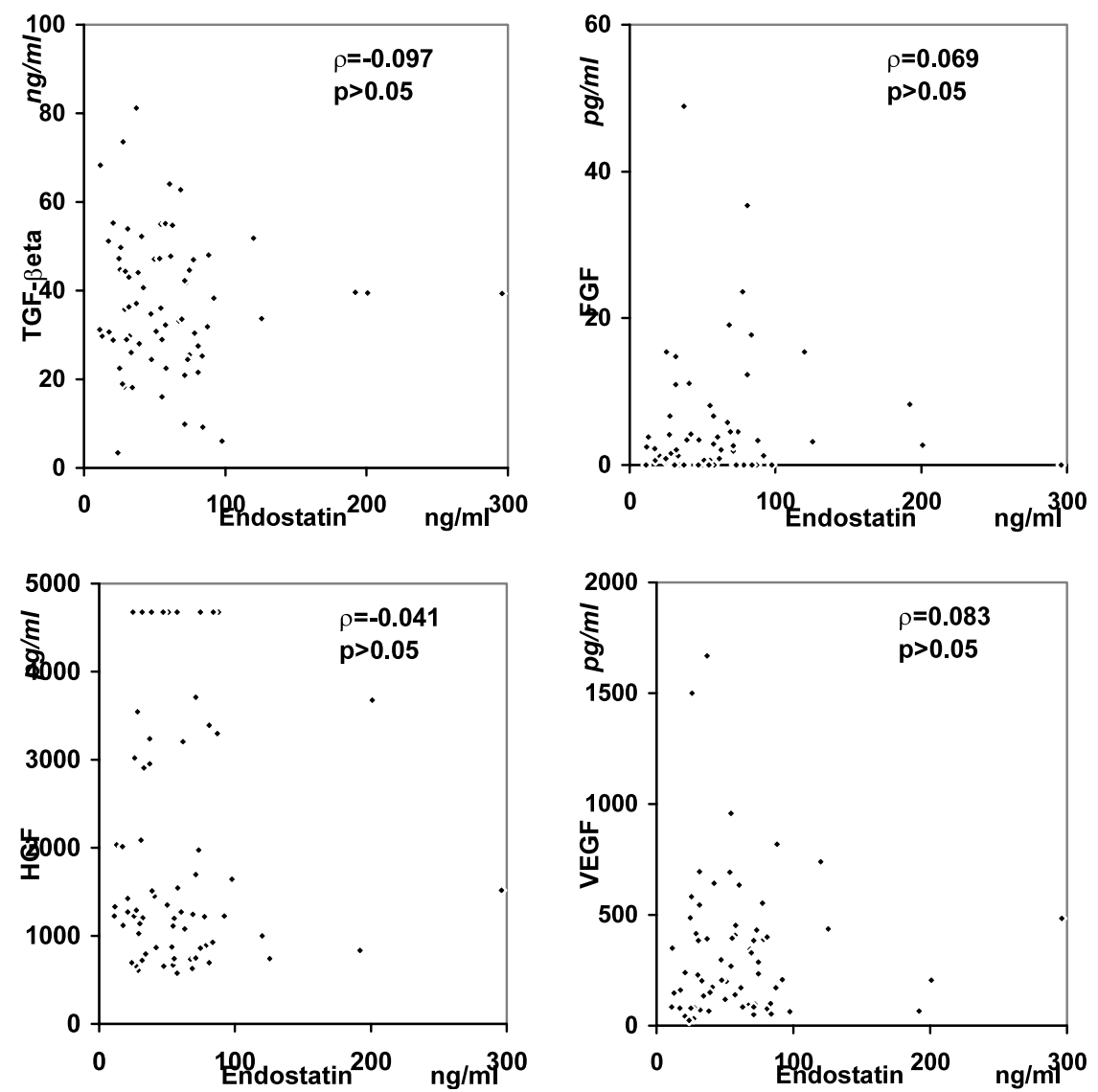

FIG. 1. Correlation between serum levels of endostatin and VEGF, HGF, TGF- $\beta 1$ and FGF. 


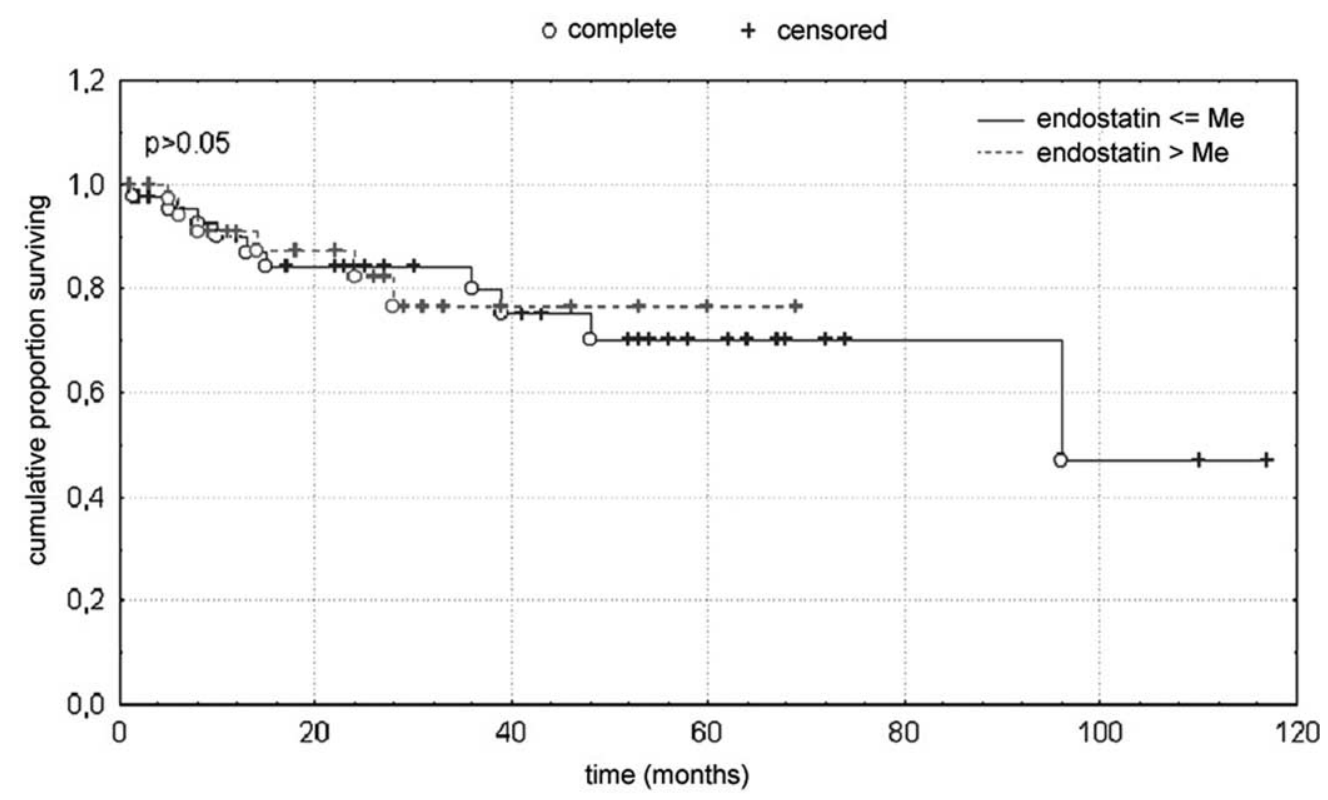

FIG. 2. The probability of survival for MM patients with high and low ( $>$ median and $<$ median) concentrations of endostatin.

latter group was composed of 167 patients whereas the former was two times smaller, and probably these proportions might influence the obtained results, so further studies are needed in this field.

In conclusion, the present study is to our knowledge the first report analysing the serum concentration and clinical significance of endostatin in a large group of MM patients. Our data suggest that serum endostatin levels are elevated in MM patients. The elevated serum values of this agent are especially relevant in patients before treatment and this is caused by the high tumour mass at the beginning of the disease. After treatment the level of this inhibitor falls, and perhaps enables in that way the intensification of angiogenesis during progression of the disease. The plateau phase of MM seems then to be the best time to apply therapy with endostatin.

ACKNOWLEDGEMENTS. This work was supported by a grant from the Medical University of Lódź (No. 502-11-658). The authors thank Ms Jolanta Fryczak for her valuable technical assistance and Ms Elżbieta Dziankowska for statistical analysis of the data.

\section{References}

1. Hanahan D, Folkman J. Patterns and emerging mechanisms of the angiogenic switch during tumorigenesis. Cell 1996; 86: 353-364.

2. Kerbel R. Tumor angiogenesis: past, present and the near future Carcinogenesis 2000; 21: 505-515.

3. Prehn R. The inhibition of tumor growth by tumor mass. Cancer Res 1991; 51: $2-4$.

4. O'Reilly MS, Boehm T, Shing Y, et al. Endostatin: an endogenous inhibitor of angiogenesis and tumor growth. Cell 1997; 88: 277-285.

5. Dhanabal M, Volk R, Ramchandran R, Simons M, Sukhatme VP. Cloning, expression and in vitro activity of human endostatin. Biochem Biophys Res Commun 1999; 258: 345-352.

6. Yamaguchi N, Anand-Apte B, Lee M, et al. Endostatin inhibits VEGFinduced endothelial cell migration and tumor growth independently of zinc binding. EMBO J 1999; 18: 4414-4423.

7. Taddei L, Chiarugi P, Brogelli L, et al. Inhibitory effect of full-length human endostatin on in vitro angiogenesis. Biochem Biophys Res Commun 1999; 263: 340-345.
8. Dhanabal M, Ramchandran R, Waterman MJ, Lu H, Knebelmann B, Segal M, Sukhatme VP. Endostatin induces endothelial cell apoptosis. J Biol Chem 1999; 274: 11721-11726.

9. Dixelius J, Larsson H, Sasaki T, et al. Endostatin induces tyrisine kinase signaling through the Shb adaptor protein regulates endothelial cell apoptosis. Blood 2000; 95: 3403-3411.

10. Kim YM, Jang JW, Lee OH, et al. Endostatin inhibits endothelial and tumor cellular invasion by blocking the activation and catalytic activity of matrix metalloproteinase. Cancer Res 2000; 60: 5410-5413.

11. Shichiri M, Hirata Y. Antiangiogenesis signals by endostatin. FASEB J 2001; 15: 1044-1053.

12. Hohenester E, Sasaki T, Olsen BR, Timpl R. Crystal structure of the angiogenesis inhibitor endostatin at $1.5 \AA$ resolution. EMBO J 1998; 17: $1656-1664$.

13. Mac Donald NJ, Shivers WY, Narum DL, et al. Endostatin binds tropomyosin. A potential modulator of the antitumor activity of endostatin. J Biol Chem 2001; 276: 25190-25196.

14. Wu P, Yonekura $\mathrm{H}, \mathrm{Li} \mathrm{H}$, et al. Hypoxia down-regulates endostatin production by human microvascular endothelial cells and pericytes. Biochem Biophys Res Commun 2001; 288: 1149-1154.

15. Bertolini F, Fusetti L, Mancuso P, et al. Endostatin, an antiangiogenic drug, induces tumor stabilization after chemotherapy or anti-CD20 therapy in a NOD/SCID mouse model of human high-grade nonHodgkin lymphoma. Blood 2000; 96: 282-287.

16. Kisker O, Becker CM, Prox D, et al. Continuous administration of endostatin by intraperitoneally implanted osmotic pump improves the efficacy and potency of therapy in a mouse xenograft tumor model. Cancer Res 2001; 61: 7669-7674.

17. Jin X, Bookstein R, Wills K, et al. Evaluation of endostatin antiangiogenesis gene therapy in vitro and in vivo. Cancer Gene Ther 2001; 12: $982-$ 989

18. Mundhenke $\mathrm{Ch}$, Thomas JP, Wilding G, et al. Tissue examination to monitor antiangiogenic therapy: a phase I clinical trial with endostatin. Clin Cancer Res 2001; 7: 3366-3374.

19. Fujii R, Yaccoby S, Epstein J. Control of myeloma growth with the antiangiogenic agent endostatin. Blood 2000; 96: 360a.

20. Tosi P, Tura S. Antiangiogenic therapy in multiple myeloma. Acta Haematol 2001; 106: 208-213.

21. Feldman AL, Pak H, Yang JC, Alexander Jr HR, Libutti SK. Serum endostatin levels are elevated in patients with soft tissue sarcoma. Cancer 2001; 91: 1525-1529.

22. Feldman AL, Tamarkin L, Paciotti GF, et al. Serum endostatin levels are elevated and correlate with serum vascular endothelial growth factor levels in patients with stage IV clear cell renal cancer. Clin Cancer Res 2000; 6: 4628-4634.

23. Nagashima M, Asano G, Yoshino S. Imbalance in production between vascular endothelial growth factor and endostatin in patients with rheumatoid arthritis. J Rheumatol 2000; 10: 2339-2342.

24. Talks KL, Harris AL. Current status of antiangiogenic factors. $\mathrm{Br}$ Haematol 2000; 109: 477-489.

25. Zorick TS, Mustacchi Z, Bando SY, Zatz M, Moreira-Filho CA, Olsen B, Passos-Bueno MR. High serum endostatin levels in Down syndrome: implications for improved treatment and prevention of solid tumors. Eur J Human Genet 2001; 11: 811-814. 
26. Robak E, Woźniacka A, Sysa-Jędrzejowska A, Stępień H, Robak T. Circulating angiogenesis inhibitor endostatin and positive endothelial growth regulators in patients with systemic lupus erythematosus. Lupus 2002; 11: 348-355.

27. Kay NE, Bone ND, Tschumper RC, et al. B-CLL cells are capable of synthesis and secretion of both pro- and anti-angiogenic molecules. Leukemia 2000; 16: 911-919.

28. Urbańska-Ryś H, Wierzbowska A, Robak T. Circulating angiogenic cytokines in multiple myeloma and related disorders. Eur Cytokine Network 2003; 14: 40-51.

29. Durie BGM, Salmon SE A clinical staging system for myeloma: correlation of measured myeloma cell mass with presenting clinical features, response to treatment and survival. Cancer 1975; 36: 842-854.

30. Urbańska-Ryś H, Wierzbowska A, Stępień H, Robak T. Relationship between circulating interleukin-10 (IL-10) with interleukin-6 (IL-6) type cytokines, interleukin-11 (IL-11), oncostatin M (OSM), and soluble interleukin-6 receptor (sIL-6R) in patients with multiple myeloma. Eur Cytokine Network 2000; 11: 443-451.

31. Wierzbowska A, Urbańska-Ryś H, Robak T. Circulating IL-6 type cytokines and sIL-6R in patients with multiple myeloma. Br J Haematol 1999; 105: 412-419.

32. Lai R, Estey E, Shen Y, et al. Clinical significance of plasma endostatin in acute leukemia/myelodysplastic syndrome. Cancer 2002; 94: 14-17.

\section{Received 12 May 2003 \\ Accepted 19 June 2003}




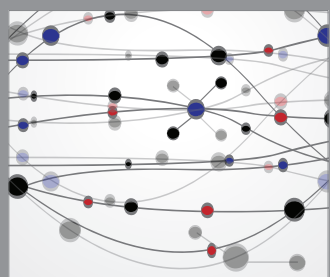

The Scientific World Journal
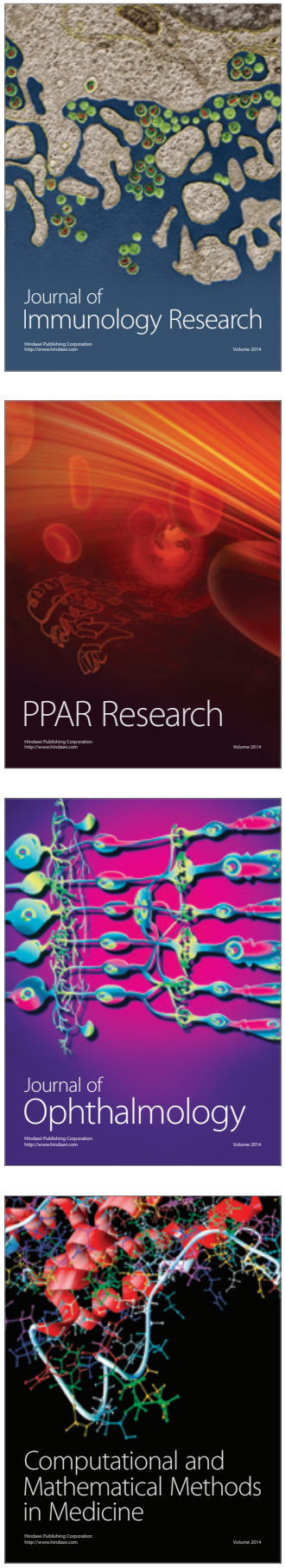

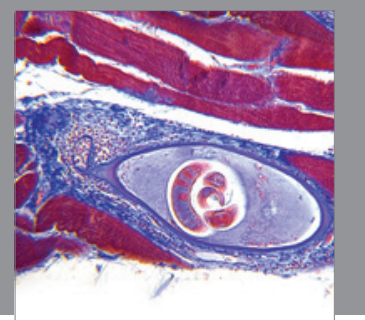

Gastroenterology

Research and Practice
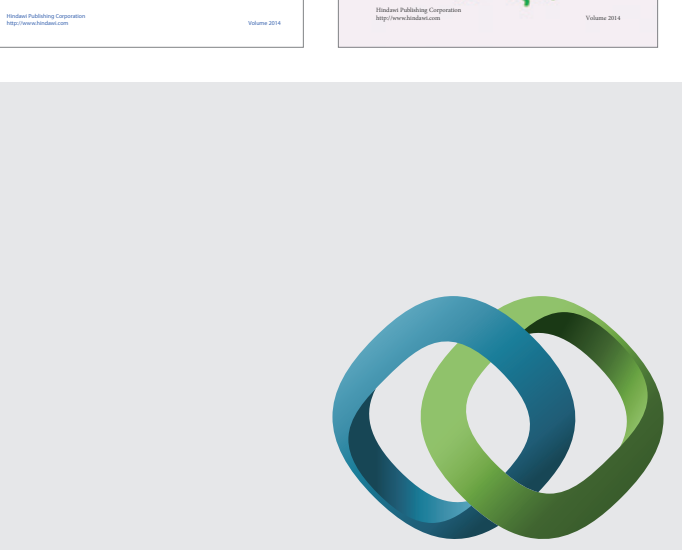

\section{Hindawi}

Submit your manuscripts at

http://www.hindawi.com
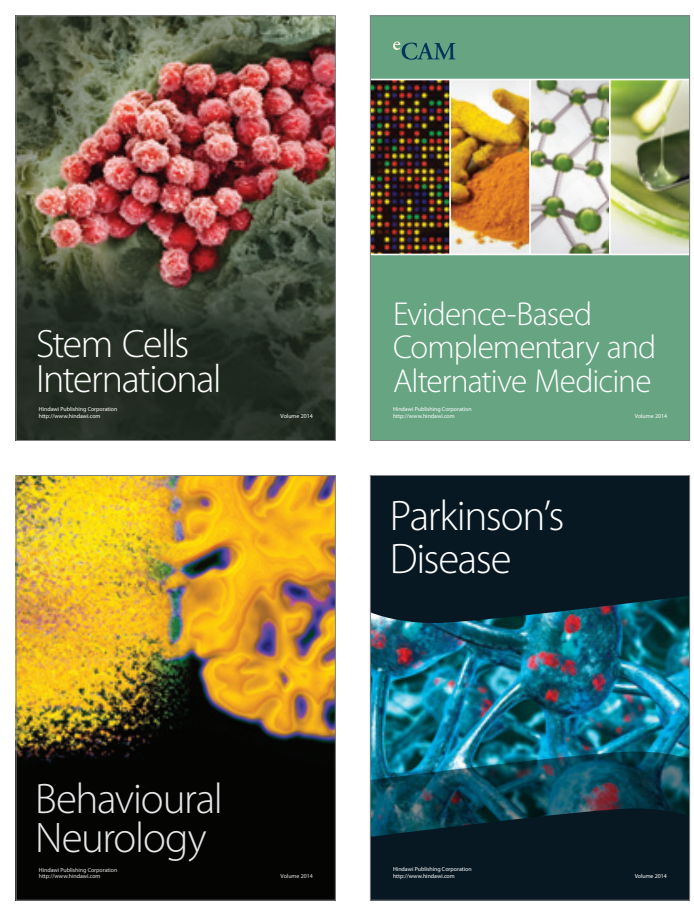

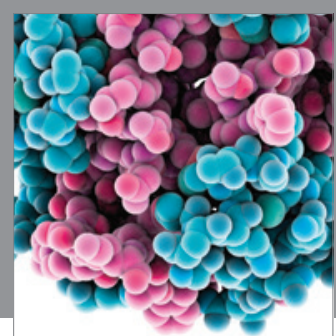

Journal of
Diabetes Research

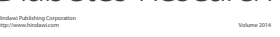



Disease Markers
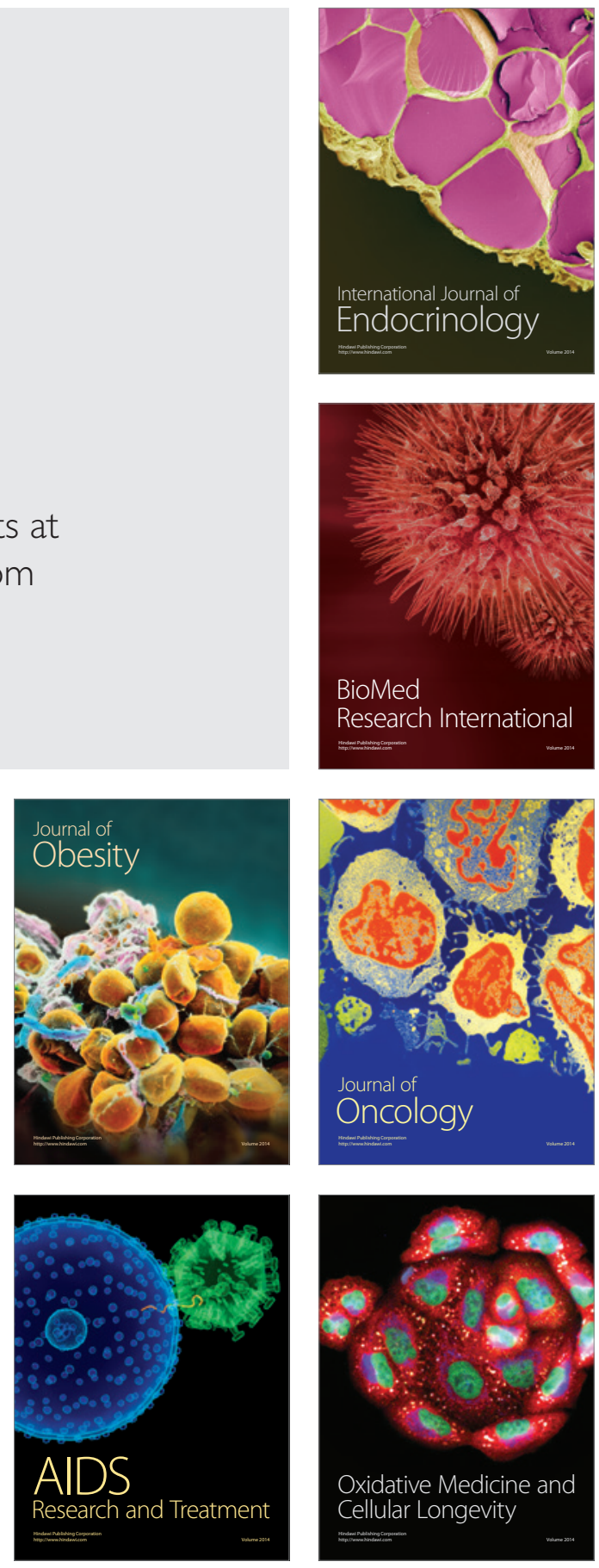